\title{
Bone Protrusion That We Should be Aware of: Foraminal Osteophytes; Classification and Surgical Results
}

\author{
Farkında Olmamız Gereken Kemik Çıkıntı: Foraminal Osteofitler; \\ Sınıflama ve Cerrahi Sonuçlar
}

\section{Ahmet Öğrenci}

Neurospinal Academy, Neurosurgery, Istanbul, Turkey

\section{Abstract}

Aim: The aim is to report our surgical results and techniques and to establish a common classification system for lumbar foraminal osteophytes.

Methods: Thirty-six patients who underwent surgery at our institution were included. Because of the presence of radicular pain in these patients, after magnetic resonance imaging, computed tomography (CT) of the lumbar spine was performed to confirm foraminal stenosis. Osteophytes were classified using CT images in patients with findings of foraminal stenosis related to osteophyte formation. Preoperative and postoperative visual analouge scale scores for leg pain were compared.

Results: Statistical analysis revealed significant improvements after surgical treatment. Osteophytes in the lumbar foramina were examined and classified as grades 1 to 4 . A treatment algorithm for osteophyte-related radiculopathy was established.

Conclusion: Foraminal osteophytes induce radiculopathy in degenerative spine disease and have a high incidence. If there are radicular findings in degenerative lumbar diseases and problems at the foraminal level, then the size of the foramen and grade of osteophytes should be evaluated with lumbar CT. Surgical treatment can achieve significant results.

Keywords: Foraminal osteophytes, foraminal stenosis, osteophytes classification, radiculopathy

\section{Öz}

Amaç: Amaç lomber foraminal osteofitlerde cerrahi sonuçları ve tekniği paylaşıp, ortak bir sınıflama oluşturmak ve tedavi algoritması belirlemektir.

Yöntemler: Opere ettiğimiz 36 hasta çalışmaya dahil edildi. Radiküler ağrıları olan ve lomber manyetik rezonans görüntülemede foraminal stenozu olan hastalara lomber bilgisayarlı tomografi (BT) çekimi yapıldı. Osteofit formasyonuna bağlı foraminal stenozu olan ve tarafımızca buna bağlı olarak ameliyat edilen hastalarda BT görüntüleri kullanılarak belirli kriterlere göre osteofitler sınıflandırıldı. Preoperatif ve postoperatif bacak visual analog skala değerleri karşılaştıııldı.

Bulgular: istatistiksel analizde cerrahi sonrasında anlamlı iyileşme gözlendi. Ameliyat ettiğimiz hastalarda lomber foramendeki osteofitler belirli kriterlere göre sınıflandırıldı. Sınıflama grade 1'den grade 4'e kadar düzenlendi. Radikülopati nedeni olan osteofitler için bir tedavi algoritması düzenlendi.

Sonuç: Foraminal osteofitler dejeneratif omurgada radikülopati nedenidir ve önemli oranda görülürler. Dejeneratif lomber omurgada eğer radiküler bulgular var ise ve foramen seviyesinde problem görülüyor ise lomber forameni değerlendirmek ve osteofit derecesini görmek için lomber BT gerekecektir. Cerrahi tedaviler önemli sonuçlara ulaşabilmektedir.

Anahtar Sözcükler: Foraminal osteofitler, foraminal darlık, osteofit sınıflaması, radikülopati

\section{Introduction}

Osteophytes develop because of degeneration in the bone surfaces, and osteophytes in the spine are regarded as both a result of degeneration and a defensive mechanism. The occurrence of osteophytes during degeneration due to aging is increasing. Osteophytes in the lumbar region are occasionally encountered by clinicians, but most related studies focus on the anterior 
osteophytes and their effects. Posterolateral osteophytes and their clinical effects at the foraminal level, which can cause neural compression, have not been examined in any study to date. In this study, we evaluated patients treated for osteophytes at the foraminal level and developed a grading system for osteophytes based on our findings. We also described our surgical technique for foraminal osteophytes, which are a cause of radicular symptoms.

\section{Methods}

The study was retrospective. Ethical approval from relevant institution and informed consents from patients were obtained. We included patients with radiculopathy who were evaluated using both magnetic resonance imaging (MRI) and computed tomography (CT) of the lumbar spine and underwent surgery for foraminal osteophytes on one level. Patients who did not benefit from conservative treatment and had to undergo surgical treatment were also included.

We employed the following criteria for patient selection:

1. No soft tissue-disc appearance to explain radicular findings,

2. No significant angulation in the coronal plane,

3. No additional bone pathology (such as rheumatoid arthritis, osteoporosis, and ankylosing spondylitis),

4. No listhesis to narrow foramen,

5. Surgical treatment for single level foraminal osteophytes.

We included 36 patients in the study and assessed 360 lumbar foramina on sagittal CT images in the classification phase.

The following parameters were used for classification:

1. Bone spur size,

2. Corpus and end plate sclerosis,

3. Loss of height at the intervertebral disc on CT images.

The age range for patients was between 32 and 87 years (average 56.4 years). Further, 26 patients were female and 10 were male. The mean preoperative and postoperative visual analouge scale (VAS) values for leg pain were compared. The mean length of hospital stay was 1.8 days, and the mean postoperative follow-up period was 25.2 (18-54 months) months.

\section{Statistical Analysis}

For statistical analysis of this study, Statistical Package for Social Sciences version 22.0 (SPSS Inc., Chicago, IL, USA) was used. Data were calculated with the help of computer, analysis was performed using the paired Samples t-test. A $p$ value of less than 0.0001 was considered statistically significant.

\section{Results}

The mean preoperative and postoperative VAS values for leg pain were $7.864 \pm 1.322$ and $2.205 \pm 1.212$ $(p<0.0001)$ (Table 1). Surgical treatment was highly effective in relieving radicular complaints. Foraminal distributions for patients were as follows: twenty nine L5, five $L 4$, one $L 2$, and $1 \mathrm{~L} 3$.

After surgical treatment, one patient experienced temporary causalgia due to root dermatome decompression in the foramen and spontaneously recovered within a few days.

The lumbar foramina were examined for all patients, and osteophytes were graded. Measurements using sagittal CT revealed that the foramen narrowed due to an osteophytic spur on the sagittal plane. A collapsed intervertebral disc was also the second leading cause of foraminal narrowing. Osteophytes were classified as follows:

Grade 1: Osteophytes appeared to disrupt the integrity of the bone surface. No narrowing of the foramen was observed at the sagittal plane. Foraminal height was unaffected, and intervertebral disc distance was generally preserved (Figure 1).

Grade 2: Osteophytes protruded from the bone surface. Sclerotic surfaces were sometimes visible. The integrity of the foramen had begun to deteriorate in the sagittal plane, but the foramen was not significantly narrow (Figure 2).

Grade 3: Narrowed foramen due to osteophytes was apparent. The transverse diameter of the foramen at the sagittal plane was smaller by $\geq 50 \%$.

The bone spur was conspicuously protuberant. Sclerosis could be seen, and the intervertebral disc had nearly collapsed (Figure 3).

Grade 4: Osteophyte duplicated the foramen. The integrity of the foramen had completely deteriorated in the sagittal plane. There was definite collapse at the intervertebral disc space. Foraminal stenosis was evident due to a collapse of the disc distance, and "foraminal duplication" could be seen (Figure 4).

We also recorded the surgical techniques used. For 12 patients, the foraminal osteophyte was extended in the lateral direction according to the facet joint, and stabilization was performed because of shaving/excision of the facet joints.

\begin{tabular}{|l|l|l|}
\hline \multicolumn{2}{|l|}{$\begin{array}{l}\text { Table 1. Comparison of visual analouge scale values for leg } \\
\text { pain between preoperative and postoperative periods }\end{array}$} & $\begin{array}{l}\text { Mean } \pm \text { standard } \\
\text { deviation }\end{array}$ \\
\cline { 1 - 2 } & \multirow{2}{*}{$<0.0001$} \\
\hline Preoperative VAS for leg pain & $7.864 \pm 1.322$ & \\
\hline Postoperative VAS for leg pain & $2.205 \pm 1.212$ & \\
\cline { 1 - 2 } & & \\
\hline
\end{tabular}




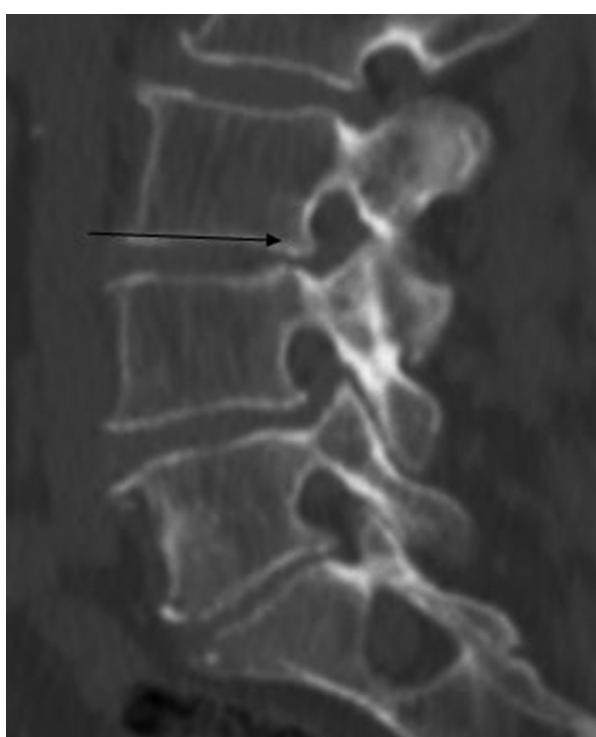

Figure 1. Grade 1 osteophyte

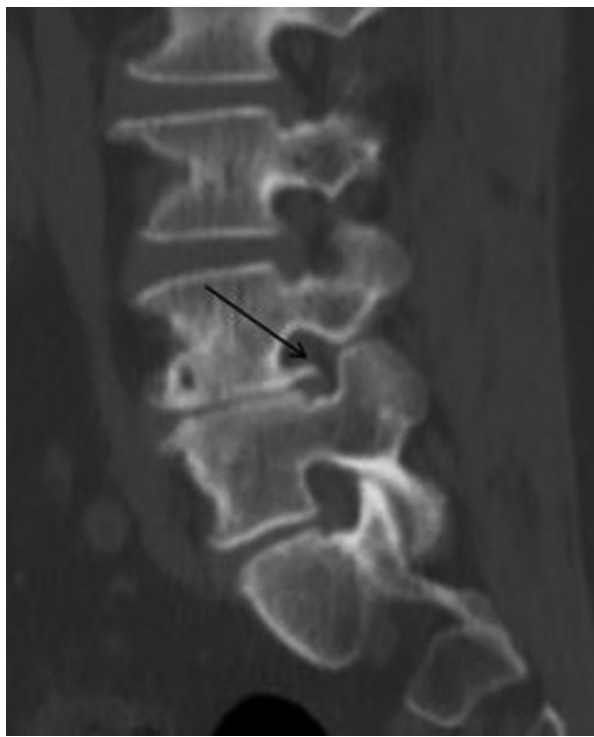

Figure 2. Grade 2 osteophyte

Decompression (foraminotomy+osteofitectomy) was sufficient for 24 patients (Table 2 ), and radicular symptoms decreased in all patients after treatment.

\section{Case 1}

A 44-year-old female patient presented with severe pain in her left leg (VAS 9) and foot drop after a long trip with prolonged sitting. Lumbar MRI of the patient, who previously underwent surgery for left L5-S1 disc herniation, showed compression at the left foraminal level of the L5 root. Soft disc herniation was not considered due to the collapse of the intervertebral disc, and lumbar CT was performed. A grade 3 osteophyte originating from the

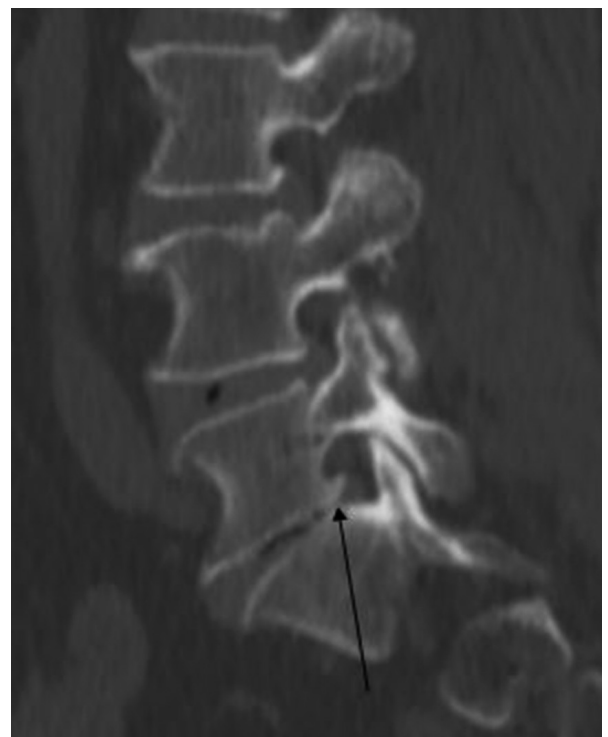

Figure 3. Grade 3 osteophyte

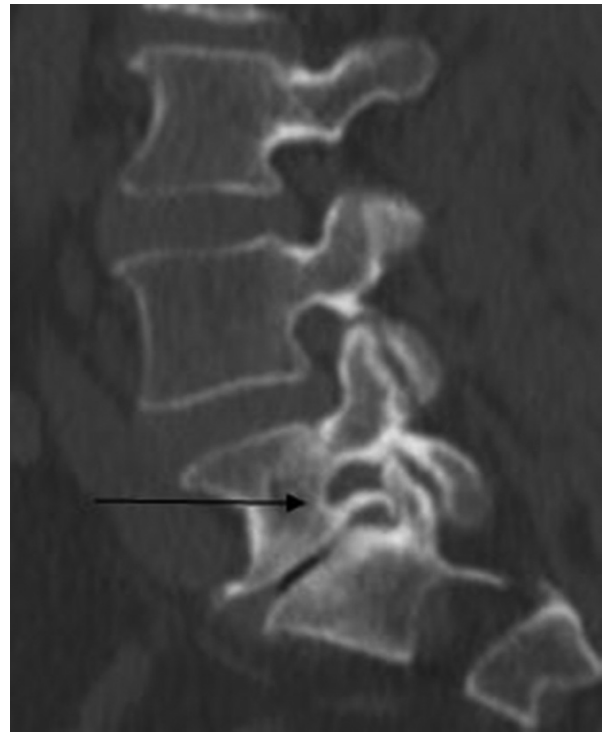

Figure 4. Grade 4 osteophyte

upper end plate (lower border of L5 corpus) was observed on lumbar CT. She was injected with a local anesthetic (2 cc $0.25 \%$ bupivacaine) in the left L5 foramen. Once the pain temporarily improved, she underwent surgical treatment for severe motor deficits. After osteophyte resection, she experienced significant improvements in motor deficits and pain (Figure 5). Postoperative leg pain score was 1 at the first month.

\section{Case 2}

This 48-year-old male patient was receiving medical treatment (gabapentin, for 12 years) for long-term low back and left leg pain. He underwent lumbar MRI due to 
complaints of increased pain (VAS for left leg pain, 10). Foraminal stenosis was observed in the left L5 foramen. Due to reduction in the intervertebral disc distance, the problem was considered to be related to osteophytes, and the patient underwent lumbar CT. A grade 3 osteophyte in the left L5 foramen was observed on lumbar CT (Figure 6). Transforaminal injection ( $2 \mathrm{~mL} 0.25 \%$ bupivacaine +40 mg methylprednisolone acetate) was administered firstly because of the absence of neurodeficits. Surgical treatment was planned for the patient when pain control could not be achieved. Because he suffered from chronic low back pain and lateralization of the osteophyte according to the facet joint, facetectomy and osteophyte resection were performed along with stabilization. Postoperative VAS score for leg pain was 2 at the first month. He discontinued the long-term medical treatment (gabapentin) on postoperative day three.

\section{Surgical Technique}

The patient was placed in the prone position under general anesthesia. Paravertebral muscles were laterally stripped on the side of the surgery. The root was found after laminotomy or hemilaminectomy at the operation side. The lamina at the same location as the root (e.g., L5 laminotomy for L5 root decompression) was excised upwards. After the root was found, it was laterally followed. The foramen narrowed due to the collapse of the intervertebral space and osteophyte. The bone protrusion-osteophyte-was fractured and excised using an appropriately sized osteotome. The osteotome was tilted from the medial to the lateral direction in an attempt to break the bone protrusion (Figure 7). Few important points should be noted at this stage:

1. If the osteophyte is more laterally located than the anterior articulation point of the facet joint, then resection may be inadequate and excising the facet joints may be necessary. Adding stabilization at this stage will prevent possible instability during the postoperative period.

2. Removal of the bony protrusion in one piece while breaking the osteotome will help ensure complete decompression. It is difficult to remove lateralized portions piece by piece, but removing the spur with osteotome in one piece may enable unblock extraction and complete decompression without excision of the facet joint.

3. The placement of the facet joint according to the sagittal plane is also important for preserving the facet joint. Preservation of sagittal orientated facet joints is more difficult because of the angulation of facet articulation faces.

Generally, the contused root rapidly recovers after decompression. If no further intervention is needed, then the surgery is terminated.

\section{Discussion}

Vertebral osteophytes depend on degeneration of the nucleus pulposus in the intervertebral discs. Over time, degeneration of the nucleus pulposus leads to a loss of

\begin{tabular}{|c|c|c|c|c|}
\hline & Grade 2 & Grade 3 & Grade 4 & Total \\
\hline Number of cases & 2 & 29 & 5 & 36 \\
\hline Stabilization & 1 * & $8^{* \star}$ & 3 & 12 \\
\hline L2 foramen & 1 & - & - & 1 \\
\hline L3 foramen & 1 & - & - & 1 \\
\hline L4 foramen & - & 5 & - & 5 \\
\hline L5 foramen & - & 24 & 5 & 29 \\
\hline \multicolumn{5}{|c|}{$\begin{array}{l}{ }^{*} \text { This patient had osteophytes in the L2 foramen. }{ }^{*} \text { Four patients in this group } \\
\text { had osteophytes in the L5 foramen, and other four patients had osteophytes } \\
\text { in the L4 foramen }\end{array}$} \\
\hline
\end{tabular}

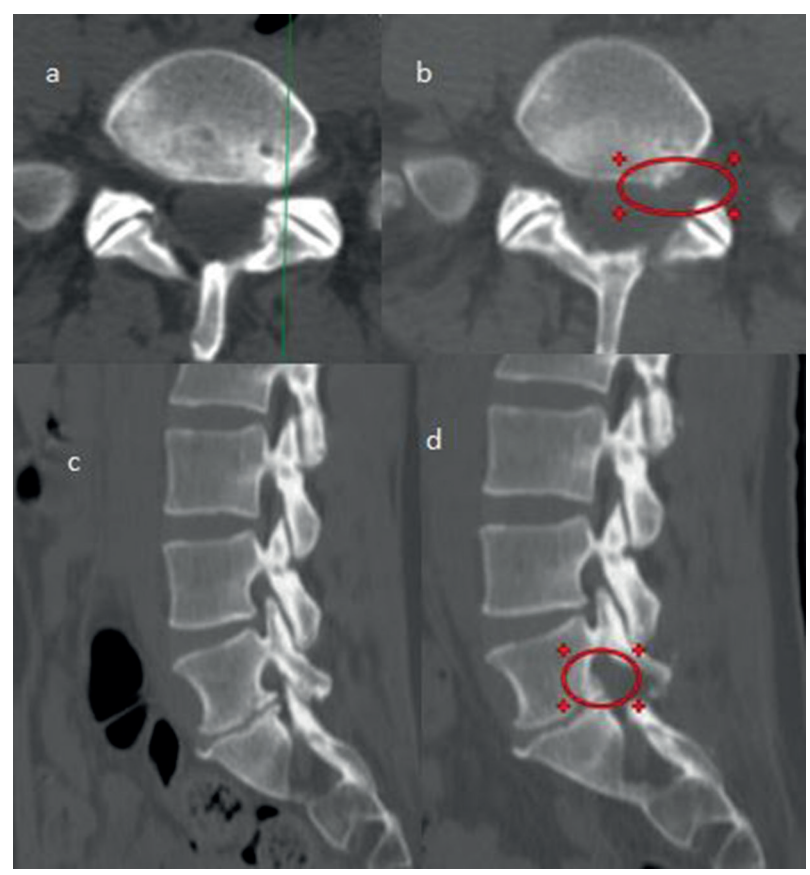

Figure 5. a) Osteophyte formation can be observed in the L5 left foramen. b) Postoperative axial image shows decompression, indicating that the foramen was expanded. Decompression was performed with hemilaminectomy and osteophytectomy. Osteophytic spur can be seen at the medial side of the vertical red line (a) which cross from the anterior point of articulation faces of facet joint. Therefore, the facet joint could be protected. Preoperative (c) and postoperative (d) sagittal computed tomography images also showed differences after surgical treatment. The patient's complaint of left leg pain dramatically decreased after surgery 


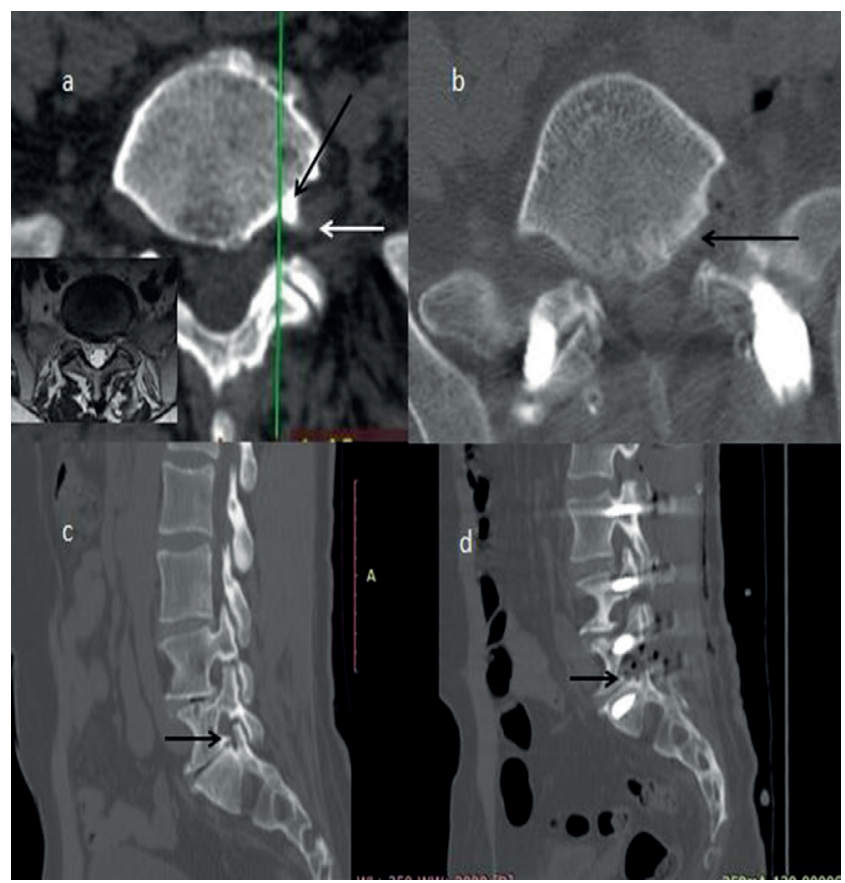

Figure 6. a) Axial magnetic resonance and computed tomography (CT) images show how the root (white arrow) was compressed by a grade 3 osteophyte (black arrow). CT image shows that this is purely osseous pathology. b) Black arrow in postoperative axial $\mathrm{CT}$ section shows decompression. An osteophytic spur can be seen on the lateral side of the vertical red line, (a) which crosses from the anterior point of the articulation faces of the facet joint. Facetectomy and osteophytectomy were performed for L5 root decompression. In addition to facetectomy, the patient was stabilized because of chronic low back pain. Black arrows in preoperative (c) and postoperative (d) sagittal CT sections show differences after surgical treatment. Left radicular pain completely regressed

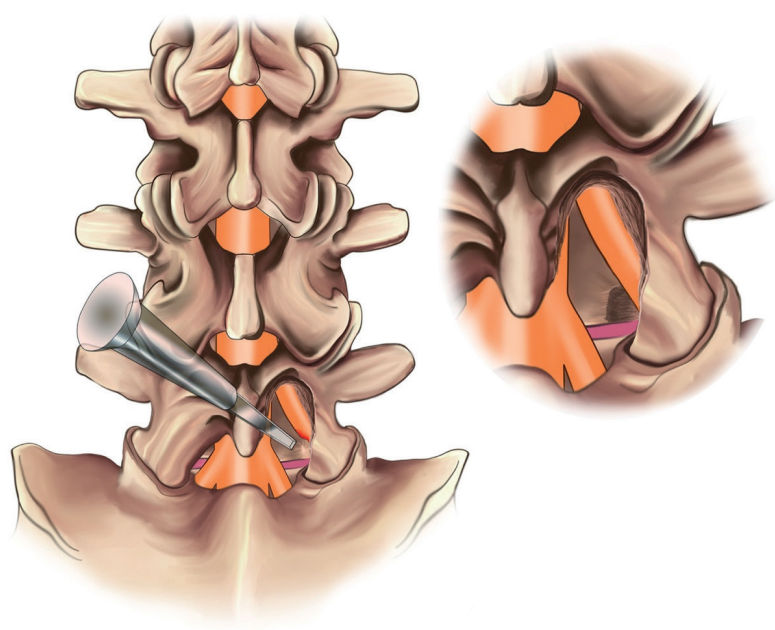

Figure 7. Surgical opening, osteophyte resection, nerve roots, and post-decompression view intervertebral disc height and diminished load-sharing capacity. Osteophytes occur due to an attempt to increase the weight distribution surface.

Reduced disc height is also associated with intervertebral disc calcification $(1,2)$.

Numerous reports have been published discussing osteoarthritis in extremities that concern orthopedists. Some of these involve narrowing of the joint space, bone sclerosis, and hypertrophy $(3,4)$. We conducted our study based on similar changes in the vertebrae. Pye et al. (5) have shown that increased osteophyte formation is associated with decreased disc space, but the level of collapse of the intervertebral disc is not always correlated with the degree of osteophyte formation $(1,6)$.

Osteophytes can form at all levels of the lumbar vertebrae. Previous studies have shown that the probability of osteophyte formation above a certain age is very high and that osteophytes can be found at all levels. Osteophytes form at inappropriate locations on the body and, therefore, compress adjacent tissues.

Anteriorly located osteophytes have always been of interest. Patients with associated vascular compression symptoms have been reported (7-9). Posteriorly located osteophytes cause neural compression.

No studies to date have reported on posterolateral osteophytes that can develop in the foramen. This report describes the first classification system for foraminal osteophytes and outcomes of surgical treatments.

Osteophytes are found $100 \%$ in the elderly, this indicates a necessity for better understanding of the associated effects.

Neurosurgeons are often interested in neural decompression and foraminotomy. In addition to soft tissue excision (i.e., disc, flavum), it is necessary to recognize that osteophytes can cause serious foraminal compression at the posterolateral side of the corpus. Therefore, the development of a common classification system is necessary.

Various classification systems for vertebral osteophytes have been reported. However, none of these systems have considered the foraminal pressure (except Lee's study, but it is not directly related to osteophytes), and they are mostly related to the shape and extent of osteophytes. Nearly all of these classification systems were applied to anteriorly located osteophytes. We developed a classification system by examining osteophytes in the foramen and consequences of these osteophytes.

The first comprehensive study on vertebral osteophytes was conducted by Nathan (10) and involved anterior claw osteophytes. Later studies progressed as extensions of this study. Vertebral osteophytes were later classified as traction, claw, or mixed type by McNAb in 1971 (11). 
He suggested that osteophytes protrude $2 \mathrm{~mm}$ from the vertebral corpus. Thereafter, different studies were conducted to investigate the severity and orientation of the protrusion of osteophytes from the surface (12-14).

Yuichi Kasai's study also classified anterior vertebral osteophytes according to their orientation. This classification, which is based on the association of spurs from the lower and upper end platelets, does not provide new data on neural compression related to osteophytes (12).

The appearance of osteophytes indicates a deterioration of stability and is thought to be an attempt to provide stability. Even, it has even been shown that anterior osteophytes are regressed in instrumented patients (15). However, some surgeons have observed that posterior or posterolateral osteophytes, which we studied here, do not regress $(16,17)$. Osteophytes limit movement and cause pain, and their excision leads to an increase in lumbar movement. In addition, foraminal osteophytes may cause neural compression, and if they do not benefit from conventional treatments, then excision of osteophytes will induce recovery from radicular complaints. This procedure is known as cheilectomy in the orthopedic community and should be called foraminal osteophytectomy for the lumbar vertebra. There was a positive correlation between the size of lumbar vertebral osteophytes and age of patients. Some studies have indicated that osteophytes are caused by aging changes. Some reports even estimate age according to the osteophyte rating (18$20)$. According to Stewart (14), there is a $75 \%$ probability of osteophyte formation in patients aged $>20$ years and $100 \%$ probability of vertebral osteophyte formation in patients aged $>40$ years. According to Chanapa et al. (21), patients aged $>35$ years definitely have vertebral osteophytes. Our study included patients who underwent surgical treatment at nearly 30 years of age. We observed an increase in osteophyte ratios as the age increased. The study by Chanapa et al. (21) is the largest study on lumbar osteophytes. In the study, lumbar osteophytes were separated according to the locations of the vertebrae for the first time and posterolateral appearance rates were reported. Osteophytes on the upper and lower surfaces of the corpus were also recorded for each level. According to the authors, the least visible places are the left and right posterolaterals, i.e., the foraminal levels. There is an increase in the rate and severity of osteophyte appearance from the upper to the lower levels of the lumbar foramina (21).

In our study, the majority of patients underwent surgery for osteophytes in the lower lumbar levels. Particularly, higher grades of osteophytes in the L4 and L5 foramina were observed and these were more common.
For our classification system, we evaluated osteophytes that developed from the lower end plates of the upper corpus. This was because osteophytes more frequently develop in the lower end plates of the upper corpus and induce radicular complaints because of the closer relation to the root when exiting the foramen (the uppermost part of the foramen).

Lee published a classification of foraminal stenosis not directly related to osteophytes. This classification system uses perineural fat obliteration, disc space narrowing, thickened ligamentum flavum, facet arthropathy, and disc osteophytic protrusion. However, the system does not provide an idea on foraminal osteophytes and surgical options for the pathology because the study was radiological and was conducted using MRI (22).

In a subsequent study, the clinical correlation with foraminal stenosis was studied using MRI. Clinical correlation has been determined based on neurological examination, but neurological assessment does not always indicate the correct nerve root. In the study, several causes of foraminal stenosis were evaluated together, but surgical options were not explored (23).

Patients with slowly developing pathology may sometimes present with acute symptoms. When the treatment of patients is evaluated, surgical treatment should be considered if pain control cannot be achieved with medical treatment and transforaminal steroid injections $(24,25)$.

A point worth mentioning is how much the osteophyte laterally and superiorly extends. In patients with osteophytes extending in the superior direction in the foramen, root pressure may be observed at earlier grades because of the root's course in the foramen. In our study, surgery was most frequently performed for L5 foraminal osteophytes.

Above L5, it becomes more difficult to protect the joint because the facet joints are more medialized and stabilization rates are greater (Table 2). The majority of patients in this study had grade 3 osteophytes because patients are more likely to experience clinical symptoms during this period (grade 3) and, therefore, more likely to be treated at this time. It is rather difficult to the proportion of osteophytes that affect the clinical condition because symptoms develop in some patients before the osteophyte grade has progressed. However, patients with grade 3 osteophytes dominated the group overall. Therefore, we can conclude that patients in or close to this category are likely to experience radicular complaints.

There is no need for additional intervention if osteofitectomy using an osteotome or a high-speed drill provides neural decompression after hemilaminectomy and foraminotomy (Figure 5) (Table 2). We usually use 
an osteotome because it is easier to excise osteophytes in one piece by digging underneath the protrusion and more difficult to remove the parts extending laterally after carving into the bony protrusion with a drill. This process was sufficient for 24 patients. However, if the root pressure persists beyond the foramen and passes through the extraforaminal section, then it is usually necessary to perform facetectomy and stabilization. An extraforaminal approach can be employed, but it is difficult to remove osteophytes with proper decompression using this approach. We performed stabilization after applying facetectomy for osteophyte resection and root decompression in 12 patients (Figure 6) (Table 2).

The presence of osteophytes at any level does not predict the existence of radiculopathy, and multiple foraminal osteophytes may be the source of radicular pain. The same surgical procedures can be performed for multiple levels, and diagnostic transforaminal injections or electromyography (EMG) can be helpful for the localization of radiculopathy. We also applied medical treatment first if the neurological deficit was not severe, followed by transforaminal injection if complaints persisted. If the patient did not benefit from these conservative methods, then we progressed to surgical treatment (Graphic).
Osteophytes can be found in a majority of the foramina. To determine the affected neural root and the root responsible for radiculopathy, clinical and radiological evaluation must be performed first. If the evaluation is insufficient or if there are doubts as to which root is responsible for the clinical condition, then we apply diagnostic injections to the foramina only with a local anesthetic. Nevertheless, we requested EMG examinations for some patients for whom we were forced to identify the responsible foramen (Graphic). These tests and injections were beneficial to diagnose some patients.

An increase in the diagnosis of posterior and posterolateral osteophytes has been reported. Our study was aimed at establishing a common discourse, classification for this situation, investigating the cause of osteophyte-related radicular symptoms, and evaluating the state of surgical treatments.

\section{Conclusion}

Studies on foraminal osteophytes are lacking, and a comprehensive classification system has not been developed to date. Surgeons should evaluate patients using CT if foraminal stenosis or osteoarthritic pathology is suspected. After clinical evaluation, it may be necessary to identify the osteophyte responsible for radicular symptoms

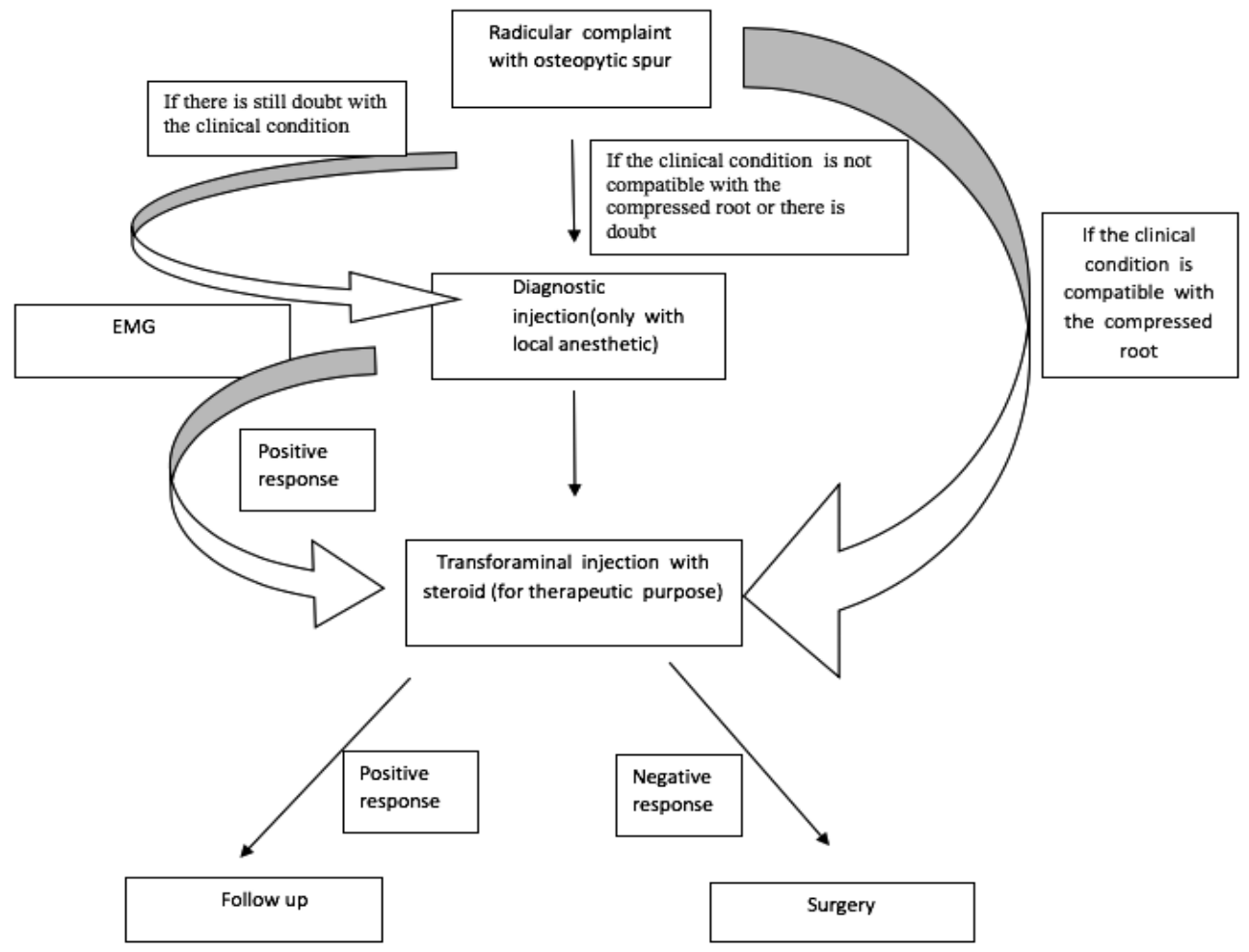

Graphic. Treatment and diagnosis methods for radiculopathy associated with foraminal osteophytes EMG: Electromyography 
using EMG and diagnostic foraminal injections. Facet joint excision may be warranted depending on localization of the osteophyte or condition of the facet when surgical treatment is required.

Significant results can be obtained using surgical treatment for radiculopathies originating from foraminal osteophytes. We aimed to create a common discourse regarding the classification of foraminal osteophytes and to share our surgical results.

Financial Disclosure: The authors declared that this study received no financial support.

\section{References}

1. Heggeness $\mathrm{MH}$, Doherty BJ. Morphologic study of lumbar vertebral osteophytes. South Med J 1998;91:187-9.

2. Hwang, JS, Chough CK, Joo WI. Giant anterior cervical osteophyte leading to Dysphagia. Korean J Spine 2013;10:200-2.

3. Sharma L, Kapoor D. Epidemiology of osteoarthritis. In: Moskowitz RW, Altman RD, Buckwalter JA, Goldberg VM, Hochberg, MC, editors. Osteoarthritis: diagnosis and medical: surgical management. 4th ed. Baltimore: Lippincott Williams \& Wilkins;2006 pp 3-27.

4. Thaper A, Zhang W, Wright G, Doherty M. Relationship between Heberden's nodes and underlying radiographic changes of osteoarthritis. Ann Rheum Dis 2005;64:1214-6.

5. Pye SR, Reid DM, Lunt M, Adams JE, Silman AJ, O'Neill TW. Lumbar disc degeneration: association between osteophytes, end-plate sclerosis and disc space narrowing. Ann Rheum Dis 2007;66:330-3.

6. Quinnell RC, Stockdale HR. The significance of osteophytes on lumbar vertebral bodies in relation to discographic findings. Clin Radiol 1982;33:197-203.

7. Karasik D, Kiel DP, Kiely DK, et al. Abdominal aortic calcification and exostoses at the hand and lumbar spine: the Framingham Study. Calcif Tissue Int 2006;78:1-8.

8. León JA, Calamia KT, Leventhal JP. Chronic obstructive pneumonia caused by a vertebral body osteophyte. Mayo Clin Proc 2000;75:185-8.

9. Scapinelli R. Compression of the inferior vena cava due to diffuse idiopathic skeletal hyperostosis. Rev Rhum Engl Ed 1997;64:198-201.
10. Nathan H. Osteophytes of the vertebral column. J Bone Joint Surg Am 1962;44:243-68.

11. Macnab I. The traction spur. An indicator of segmental instability. J Bone Joint Surg Am 1971;53:663-70.

12. Kasai Y, Kawakita E, Sakakibara T, Akeda K, Uchida A. Direction of the formation of anterior lumbar vertebral osteophytes. BMC musculoskeletal disorders 2009;10:4.

13. O'Neill TW, McCloskey EV, Kanis JA, et al. The distribution, determinants, and clinical correlates of vertebral osteophytosis: a population based survey. J Rheumatol 1999;26:842-8.

14. Stewart TD. The rate of development of vertebral osteoarthritis in American whites and its significance in skeletal age identification. Leech 1958;28:144-51.

15. Ha KY, Molon JN, Ahn JH, Kim YH. Fate of osteophytes and sclerosis in fused segments after lumbar fusion. Spine (Phila Pa 1976) 2014;39:1110-5.

16. Seo JY, Ha KY. Fate of posterior osteophytes in fused segments after anterior cervical discectomy and fusion. Spine (Phila Pa 1976) 2012;37:741-7.

17. Stevens JM, Clifton AG, Whitear P. Appearances of posterior osteophytes after sound anterior interbody fusion in the cervical spine: a high-definition computed myelographic study. Neuroradiology 1993;35:227-8.

18. Prescher A. Anatomy and pathology of the aging spine. Eur J Radiol 1998;27:181-95.

19. Snodgrass JJ: Sex differences and aging of the vertebral column. J Forensic Sci 2004;49:1-6.

20. Watanabe S, Terazawa K. Age estimation from the degree of osteophyte formation of vertebral columns in Japanese. Legal Medicine 2006;8:156-60.

21. Chanapa P, Yoshiyuki T, Mahakkanukrauh P. Distribution and length of osteophytes in the lumbar vertebrae and risk of rupture of abdominal aortic aneurysms: a study of dry bones from Chiang Mai, Thailand. Anat Cell Biol 2014;47:157-61.

22. Lee S, Lee JW, Yeom JS et al. A practical MRI grading system for lumbar foraminal stenosis. AJR Am J Roentgenol 2010;194:1095-8.

23. Park HJ, Kim SS, Lee SY et al. Clinical correlation of a new MR imaging method for assessing lumbar foraminal stenosis. AJNR Am J Neuroradiol 2012;33:818-22.

24. Lamer TJ. Lumbar spine pain originating from vertebral osteophytes. Reg Anesth Pain Med 1999;24:347-51.

25. Wong SH, Chiu KY, Yan CH. Review Article: Osteophytes. J Orthop Surg (Hong Kong) 2016;24:403-10. 